\title{
Early Age at First Sexual Intercourse is Associated with Higher Prevalence of High-grade Squamous Intraepithelial Lesions (HSIL)
}

\section{Idade precoce de início da atividade sexual está associada a elevada prevalência de Lesão Intraepitelial Escamosa de Alto Grau}

\author{
José Cândido Caldeira Xavier-Júnior ${ }^{1}$ Rozany Mucha Dufloth ${ }^{2}$ Diama Bhadra Vale ${ }^{3}$ \\ Marcelo Tavares de Lima $^{3}$ Luiz Carlos Zeferino ${ }^{3}$ \\ ${ }^{1}$ Instituto de Patologia de Araçatuba, Araçatuba, São Paulo, SP, Brazil \\ ${ }^{2}$ Hospital do Câncer de Barretos, Fundação Pio XII, Barretos, São Paulo, \\ SP, Brazil \\ ${ }^{3}$ Department of Gynecology and Obstetrics, Universidade Estadual de \\ Campinas, Campinas, São Paulo, SP, Brazil

\begin{abstract}
Address for correspondence Rozany Mucha Dufloth, MD, PhD, Department of Pathology, Hospital do Câncer de Barretos, Rua Antenor Duarte Vilella, 1.331, 14780-000 Barretos, SP, Brazil (e-mail: rozany.dufloth@gmail.com).
\end{abstract}

Rev Bras Ginecol Obstet 2017;39:80-85.

\begin{abstract}
Keywords

- cytology

- pap smear

- cervical intraepithelial neoplasia

- age groups

- sexual behavior
\end{abstract}

\section{Resumo}

Objective To evaluate the association of age at first sexual intercourse with the results of the cervicovaginal cytology.

Study Design Observational analytical study about the prevalence of altered cervicovaginal cytology results in women aged between 18 and 34 years from a densely populated area in Brazil, during 10 years. The patients were stratified into 2 categories according to their age at first sexual intercourse (13-16 years and 17-24 years).

Results From the total of 2,505,154 exams, 898,921 tests were in accordance with the inclusion criteria. Considering women with 4 years or less from the first sexual intercourse as a reference, those with 5 to 9 years and 10 years or more showed a higher prevalence of high-grade squamous intraepithelial lesions (HSILs). Women with an earlier onset of sexual intercourse (13-16 years) showed higher prevalence ratios for atypical squamous cells (ASC), low-grade squamous intraepithelial lesion (LSIL) and HSIL. The prevalence ratio for HSIL adjusted by age at diagnosis and by age at first sexual intercourse was higher only for women with an earlier onset of sexual intercourse. Conclusions The age of first sexual intercourse could be a variable that might qualify the selection among young women who are really at a higher risk for HSIL.

Objetivo Avaliar a associação entre idade de início da atividade sexual e os resultados de citologia cervico-vaginal.

Métodos Estudo observacional sobre a prevalência dos resultados de citologia cervico-vaginal alterados em mulheres com idade entre 18 e 34 anos na região de received

September 17, 2016 accepted

November 28, 2016

published online

February 23, 2017
DOI http://dx.doi.org/

10.1055/s-0036-1597973. ISSN 0100-7203.
Copyright $(2017$ by Thieme-Revinter

Publicações Ltda, Rio de Janeiro, Brazil
License terms

(c) $(1) \$$ 


\author{
Palavras-chave \\ - citologia \\ - teste de Papanicolau \\ - neoplasia \\ intraepitelial cervical \\ - grupos etários \\ - comportamento \\ sexual
}

Campinas - SP, Brasil, durante 10 anos. As pacientes foram estratificadas em dois grupos de acordo com a idade de início da atividade sexual (13 a 16 anos e 17 a 24 anos). Resultados Do total de 2.505.154 exames, 898.921 preencheram os critérios de inclusão. Considerando mulheres com tempo desde a primeira relação sexual menor ou igual a 4 anos como grupo de referência, mulheres com intervalos de 5 a 9 anos e 10 anos ou mais entre a data do exame e a primeira relação sexual mostraram maior prevalência de lesão intraepitelial escamosa de alto grau (LIEAG). Mulheres com início da atividade sexual mais precoce (13-16 anos) mostraram altas prevalências de atipia de células escamosas, lesão intraepitelial escamosa de baixo grau e LIEAG. A razão de prevalência de LIEAG ajustada pela idade na data do exame e pela idade do início da atividade sexual foi maior somente para mulheres que apresentaram início mais precoce da atividade sexual.

Conclusão A idade de início da atividade sexual pode ser uma possível variável de seleção das mulheres com maior risco de LIEAG.

\section{Introduction}

Cervical cancer is still a common neoplasia in low and middleincome countries. The human papillomavirus (HPV) infection is known as one of the steps of the carcinogenesis process. The infection is more frequent among women in the years following the first sexual intercourse. ${ }^{1,2}$ Precursor lesions can occur as a consequence of persistent infection in a process that lasts for 5 to 10 years. ${ }^{2-4}$

Screening in women younger than 25 years old is controversial. Despite there being a risk of developing cervical cancer at early ages, it is very low. ${ }^{1,5-7}$ There are suggestions that screening women under 25 years old is more harmful than beneficial, ${ }^{8}$ and does not impact cervical cancer incidence in them. ${ }^{8,9}$ Nevertheless, the decision to screen young women could be individualized for each population group.

In Brazil, there is no system for inviting women for cervical cancer screening. The national recommendation is to screen women aged 25 to 64 years old through cytology, and the high-risk HPV-test is not available. ${ }^{10}$ There are many social conditions that lead to inequality in accessing cervical cytology tests for women from different regions of the country. ${ }^{11}$ However, during 2013, around 1,301,210 cytological tests in women under 24 years old were performed in Brazil. ${ }^{12}$

Atypical squamous cells (ASCs) and low grade squamous intraepithelial lesion (LSIL) are the most frequent abnormal cytology results in young women. ${ }^{13}$ The latter is a marker of the HPV infection, and usually regresses spontaneously. ${ }^{2,4}$ In addition, the treatment for precursor lesions in this age group is related to an increased risk of premature labor due to the anatomical damage that occurs during the procedure. ${ }^{1,8}$

It has been suggested that early sexual intercourse can be a risk factor for cervical cancer in young women, ${ }^{1,14,15}$ since it is a risk factor for HPV infection. ${ }^{16}$ On the other hand, screening patients under the recommended age may impact the efficiency of a program through the improper use of the logistic and human resource structures. It is therefore necessary to perform a critical evaluation of that program perfor- mance. This study aims to analyze the relationship between age at first intercourse and abnormal cytological results based on a large sample of tests from an opportunistic screening program.

\section{Methods}

This was an observational retrospective study of the prevalence of abnormal cytology results in women aged between 18 and 34. Test results and personal data were obtained from the database of the Cytopathology Laboratory database of Hospital da Mulher Prof. Dr. José Aristodemos Pinotti, Universidade Estadual de Campinas (Unicamp), from January 2000 to December 2009 (10 years). The laboratory performs cytology analyses of all public health services of almost 70 municipalities in the Campinas region, a densely populated urban area in the State of São Paulo, Brazil. Institutional Review Board (IRB) approval was obtained from Unicamp, and informed consent was dispensed, as this was a database analysis with no individual identification.

Smears were collected by physicians or nurses in healthcare units as part of the routine care of women. Information on current age, age at first sexual intercourse, the purpose of the test (screening or other), the interval between screening tests and other clinically relevant information (radiotherapy, symptoms or others) were recorded by the collector on a form sent to the laboratory with the slides. After the analyses, the cytological results were recorded on the form and added to the database by optical reading.

The study excluded incorrectly labeled tests, those classified as unsatisfactory, those that had records of a previous test within the last year or with a purpose other than screening. The nomenclature of the results was in accordance with Bethesda 2001. ${ }^{17}$ Since the database included results from before the new nomenclature, the results atypical squamous cells of undetermined significance (ASC-US) and atypical squamous cells cannot exclude high-grade squamous intraepithelial lesion (ASC-HSIL) were included together as ASCs. ${ }^{18}$ 
Therefore, the following results were included in this study: negative for intraepithelial lesion or malignancy, ASC, LSIL, and HSIL.

Women were stratified by age group in 4 categories for trend analyses (18-19 years; 20-24 years; 25-29 years; and 30-34 years), and 3 categories for multivariate analyses (18-24 years; $25-29$ years; and 30-34 years). Two groups were created for analysis according to age at first sexual intercourse considering the mean age at first sexual intercourse as the point: $13-16$ years old and 17-24 years old. In order to analyze time since the first sexual intercourse, 3 intervals were created: $0-4$ years; $5-9$ years; and 10 or more years. The frequencies of the results were described as prevalence of tests. In order to analyze the trend of HSIL in relation to the other cytological results for different age groups, the Cochran-Armitage Trend Test was used. Values of $p<0.05$ were considered statistically significant. The prevalence ratio (PR) with 95\% confidence intervals (95\% $\mathrm{CI}$ ) was estimated. To test the association, the chi-square test and multivariate analysis of log-binomial regression model to estimate the adjusted PR were used. A PR greater than 1 was considered a risk factor, and less than 1 , a protective factor, if the value 1 was not included in the CIs.

\section{Results}

After using the exclusion criteria, the sample consisted of 898,921 tests out of the 2,505,154 tests performed from 2000 to 2009 . The mean age of the women was 26 years, and the mean age at first sexual intercourse was 17 years.

The prevalence of the cytology results per 100 tests for negative, ASC, LSIL and HSIL was of 97.65, 1.21, 0.80 and 0.36 respectively. With increasing age, the prevalence of ASC and LSIL tended to decrease (Trend test $p<0.001$ ), while the prevalence of negative results tended to increase (Trend test $p<0.001$ ) (-Table 1).

With recent first sexual intercourse (0-4 years) as a reference group, intermediate first sexual intercourse (5-9 years) protected for the LSIL result (PR: 0.73 ; 95\%CI: $0.69-$
0.77) and was a risk for the HSIL result (PR: 1.39; 95\%CI: $1.25-$ 1.54). Late first sexual intercourse ( $\geq 10$ years) protected for the ASC (PR: 0.82; 95\%CI: 0.78-0.86) and LSIL results (PR: 0.44 ; 95\%CI: $0.44-0.50)$, and was a risk for the HSIL result (PR: 1.41; 95\%CI: 1.28-1.56) (-Table 2).

For the three age groups analyzed, early age at first sexual intercourse was a risk for the ASC, LSIL and HSIL results (-Table 3). In the multivariate analysis of log-binomial regression model, considering HSIL as a reference category, age was not a significant variable, while the age at first sexual intercourse between 13 and 17 years has remained a risk factor (-Table 4).

\section{Discussion}

This study has shown that age at first sexual intercourse under 17 years was a risk factor for HSIL regardless of the age of the women. Besides that, five or more years since the first sexual intercourse were associated to HSIL in agreement with cervical cancer natural history.

There are suggestions that delaying the first screening might increase the risk of cancer, ${ }^{1}$ reinforcing the association between age at first sexual intercourse and cervical cancer. ${ }^{19}$ Biological immaturity and hormonal influence are considered two possible explanations for the association between early sexual experience and a higher risk of cervical cancer. ${ }^{16,20}$ Some studies reinforce that screening sexually active populations under 25 years is useful, since the rates of cervical intraepithelial neoplasia (CIN) 3 are not insignificant: 1.7. This point is in agreement with American guidelines, which recommend screening patients by the age of 21 years. $^{21}$

On the other hand, cervical cancer is very rare among women under 25 years. $^{2,4,6}$ Screening young populations requires a great number of cytological examinations and frequent references to colposcopy analyses with weak impact on prognosis. ${ }^{6}$ In addition, preterm birth and low-birth weight are related to the overtreatment of young patients with pre-cancer lesions. ${ }^{1}$

Table 1 Prevalence of cytology results per 100 tests and trends in women aged 18 to 34 years

\begin{tabular}{|c|c|c|c|c|c|c|c|c|c|}
\hline \multirow[b]{2}{*}{ Age group } & \multicolumn{2}{|c|}{$\begin{array}{l}\text { Negative for neo- } \\
\text { plasm }\end{array}$} & \multicolumn{2}{|l|}{ ASC } & \multicolumn{2}{|l|}{ LSIL } & \multicolumn{2}{|l|}{ HSIL } & \multirow[b]{2}{*}{ Total } \\
\hline & $\mathrm{n}$ & $\mathrm{p}$ & $\mathrm{n}$ & $\mathrm{p}$ & $\mathrm{n}$ & $\mathrm{p}$ & $\mathrm{n}$ & $\mathrm{p}$ & \\
\hline $18-19$ years & 87,496 & 96.62 & 1,407 & 1.55 & 1,357 & 1.50 & 296 & 0.33 & 90,556 \\
\hline $20-24$ years & 271,989 & 97.19 & 3,952 & 1.41 & 2,825 & 1.01 & 1,082 & 0.39 & 279,848 \\
\hline $25-29$ years & 265,488 & 97.84 & 3,082 & 1.14 & 1,766 & 0.65 & 1,017 & 0.37 & 271,353 \\
\hline $30-34$ years & 252,823 & 98.31 & 2,454 & 0.95 & 1,075 & 0.42 & 812 & 0.32 & 257,164 \\
\hline All age groups & 877,796 & 97.65 & 10,895 & 1.21 & 7,023 & 0.80 & 3,207 & 0.36 & 898,921 \\
\hline CA statistics $^{1}$ & \multicolumn{2}{|l|}{34.66} & \multicolumn{2}{|l|}{-18.22} & \multicolumn{2}{|c|}{-35.31} & \multicolumn{2}{|l|}{-2.45} & \\
\hline$p$-value ${ }^{2}$ & \multicolumn{2}{|l|}{$<0.001$} & \multicolumn{2}{|l|}{$<0.001$} & \multicolumn{2}{|c|}{$<0.001$} & \multicolumn{2}{|c|}{$<0.001$} & \\
\hline
\end{tabular}

Abbreviations: ASC, atypical squamous cells; HSIL, high-grade squamous intraepithelial lesion; LSIL, low-grade squamous intraepithelial lesion; $\mathrm{n}$, absolute number of tests; $\mathrm{p}$, prevalence.

Notes: ${ }^{1}$ CA statistics: Statistic of Cochran-Armitage ( $>0=$ increasing trend; $<0=$ decreasing trend). ${ }^{2} p$ value for Cochran-Armitage trend test. 
Table 2 Prevalence (per 100 tests) and prevalence ratio of cytology results per 100 tests according to time since first sexual intercourse

\begin{tabular}{|l|l|l|l|l|l|l|l|l|l|l|}
\hline \multirow{2}{*}{$\begin{array}{l}\text { Time since first } \\
\text { sexual intercourse }\end{array}$} & Total & \multicolumn{2}{|l|}{ ASC } & \multicolumn{2}{l|}{ LSIL } & \multicolumn{2}{l|}{ HSIL } \\
\cline { 2 - 11 } & $\mathbf{n}$ & $\mathbf{n}$ & $\mathbf{P}$ & $\begin{array}{l}\text { PR } \\
(95 \% \mathrm{Cl})\end{array}$ & $\mathbf{n}$ & $\mathbf{P}$ & $\begin{array}{l}\text { PR } \\
(95 \% \mathrm{Cl})\end{array}$ & $\mathbf{n}$ & $\mathbf{P}$ & $\begin{array}{l}\text { PR } \\
(95 \% \mathrm{CI})\end{array}$ \\
\hline $0-4$ years & 185,896 & 2,460 & 1.32 & 1 & 2,172 & 1.17 & 1 & 501 & 0.27 & 1 \\
\hline $5-9$ years & 306,363 & 4,018 & 1.31 & $\begin{array}{l}0.99 \\
(0.94-1.04)\end{array}$ & 2,617 & 0.85 & $\begin{array}{l}0.73 \\
(0.69-0.77)\end{array}$ & 1,147 & 0.37 & $\begin{array}{l}1.39 \\
(1.25-1.54)\end{array}$ \\
\hline$\geq 10$ years & 406,662 & 4,417 & 1.08 & $\begin{array}{l}0.82 \\
(0.78-0.86)\end{array}$ & 2,234 & 0.55 & $\begin{array}{l}0.44 \\
(0.44-0.50)\end{array}$ & 1,559 & 0.38 & $\begin{array}{l}1.41 \\
(1.28-1.56)\end{array}$ \\
\hline Total & & & & 7,023 & 0.78 & & 3,207 & 0.36 & \\
\hline
\end{tabular}

Abbreviations: ASC, atypical squamous cells; HSIL, high-grade squamous intraepithelial lesion; LSIL, low-grade squamous intraepithelial lesion; $n$, absolute number of tests; $\mathrm{p}$, prevalence; PR $(95 \% \mathrm{Cl})$, prevalence ratio ( $95 \%$ confidence interval).

Despite some alterations in sexual behavior over the last years, ${ }^{1}$ changes in screening programs have postponed the age of the first screening tests, ${ }^{1,5}$ and the influence of age at first sexual intercourse as a risk factor is in discussion. ${ }^{7,15,16,19,20}$ After that, the amount of cancers at age 25 has increased dramatically; however, these cases are micro-invasive, with excellent prognosis ${ }^{5,6}$ and rare deaths. ${ }^{7}$ Therefore, there is doubt if screening women

Table 3 Prevalence (per 100 tests) and prevalence ratio of cytology results according to age group and age at first sexual intercourse

\begin{tabular}{|c|c|c|c|c|c|c|}
\hline \multirow[t]{3}{*}{ Age group } & \multirow[t]{3}{*}{ Cytology result } & \multicolumn{4}{|c|}{ Age at first sexual intercourse } & \multirow{3}{*}{$\begin{array}{l}\text { PR } \\
(95 \% \mathrm{Cl})\end{array}$} \\
\hline & & \multicolumn{2}{|c|}{$13-16$ years } & \multicolumn{2}{|c|}{$17-24$ years } & \\
\hline & & $\mathrm{n}$ & $p$ & $n$ & $\mathrm{p}$ & \\
\hline \multirow[t]{5}{*}{$18-24$ years } & Negative & 202,318 & 96.75 & 157,167 & 97.45 & - \\
\hline & ASC & 3,303 & 1.58 & 2,056 & 1.27 & $\begin{array}{l}1.25 \\
(1.18-1.32)\end{array}$ \\
\hline & LSIL & 2,569 & 1.23 & 1,613 & 1.00 & $\begin{array}{l}1.24 \\
(1.16-1.32)\end{array}$ \\
\hline & $\mathrm{HSIL}$ & 929 & 0.44 & 449 & 0.28 & $\begin{array}{l}1.61 \\
(1.44-1.80)\end{array}$ \\
\hline & Total & 209,119 & 100.00 & 161,285 & 100.00 & \\
\hline \multirow[t]{5}{*}{$25-29$ years } & Negative & 116,433 & 97.50 & 149,055 & 98.11 & - \\
\hline & ASC & 1,517 & 1.27 & 1,565 & 1.03 & $\begin{array}{l}1.11 \\
(1.07-1.14)\end{array}$ \\
\hline & LSIL & 897 & 0.75 & 869 & 0.57 & $\begin{array}{l}1.14 \\
(1.09-1.20)\end{array}$ \\
\hline & HSIL & 572 & 0.48 & 445 & 0.29 & $\begin{array}{l}1.28 \\
(1.19-1.38)\end{array}$ \\
\hline & Total & 119,419 & 100.00 & 151,934 & 100.00 & \\
\hline \multirow[t]{5}{*}{$30-34$ years } & Negative & 92,235 & 97.92 & 160,588 & 98.54 & - \\
\hline & ASC & 1,078 & 1.14 & 1,376 & 0.84 & $\begin{array}{l}1.13 \\
(1.09-1.17)\end{array}$ \\
\hline & LSIL & 470 & 0.50 & 605 & 0.37 & $\begin{array}{l}1.13 \\
(1.07-1.19)\end{array}$ \\
\hline & HSIL & 407 & 0.43 & 405 & 0.24 & $\begin{array}{l}1.27 \\
(1.19-1.36)\end{array}$ \\
\hline & Total & 94,190 & 100.00 & 162,974 & 100.00 & \\
\hline
\end{tabular}

Abbreviations: ASC, atypical squamous cells; HSIL, high-grade squamous intraepithelial lesion; LSIL, low-grade squamous intraepithelial lesion; n, absolute number of tests; $\mathrm{p}$, prevalence; PR ( $95 \% \mathrm{Cl})$, prevalence ratio ( $95 \%$ confidence interval). 
Table 4 Adjusted prevalence ratio for HSIL by age at diagnosis and age at first sexual intercourse (multivariate analysis of logbinomial regression model)

\begin{tabular}{|l|l|l|}
\hline Variable & Category & $\begin{array}{l}\text { Adjusted prevalence } \\
\text { ratio }(95 \% \mathrm{CI})\end{array}$ \\
\hline \multirow{2}{*}{ Age } & $18-24$ years & Reference \\
\cline { 2 - 3 } & $25-29$ years & $1.07(0.99-1.16)$ \\
\cline { 2 - 3 } & $30-34$ years & $0.94(0.86-1.02)$ \\
\hline $\begin{array}{l}\text { Age at first sexual } \\
\text { intercourse }\end{array}$ & $13-16$ years & $1.65(1.53-1.77)$ \\
\cline { 2 - 3 } & $17-24$ years & Reference \\
\hline
\end{tabular}

Abbreviations: HSIL, high-grade squamous intraepithelial lesion; $95 \% \mathrm{CI}$, 95\% confidence interval.

aged 20-24 years can impact the incidence of cancer in those under 30 years. ${ }^{6,7,9}$

These results have to be counterbalanced by the knowledge that HSIL in young groups is more representative of CIN 2, which resembles the pattern of LSIL. ${ }^{13}$ It is then necessary to highlight that cytology is the first approach on screening. Only in cases of histologically confirmed CIN 3, procedures could be considered; however, there is a low chance of progression from CIN 3 to invasive cancer in women aged 20-24 years. ${ }^{6,22}$ Another factor in women aged 20-24 years is that cervical cancer is normally at a more advanced stage and more frequently presents different histological variants when compared with women aged 25-29 years. $^{5}$

The results of increased risk of ASC-US and LSIL among young women are in agreement with cervical cancer history, since it tends to decrease with age. ${ }^{2,4}$ In these cases, they are often transient lesions representing the HPV infection. ${ }^{2,4,13}$ We should reinforce that the average age of diagnosis of pre-cancer lesions depends on the age at first sexual intercourse and the intensity of screening. ${ }^{3}$ For adolescents, the view is more conservative, and new guidelines recommend an adequate follow-up without invasive tests; due to the high regression rates of cytological abnormalities, ${ }^{14}$ health professionals should know what followup young women need.

A weakness of this study is that there is no information about histological results. On the other hand, this study has a large amount of high-quality smears for analysis, and the absence of selection. The study used information from 10 years of work, providing a good portrayal of the population.

\section{Conclusion}

There was an association between early age at first sexual intercourse and high-grade lesions, regardless of age. Nevertheless, cervical screening for women younger than 25 years remains under discussion. Therefore, public health programs should consider all diverse social and cultural patterns around the world, in order to accomplish a more suitable target age group for cancer screening. In this way, the age at first sexual intercourse could be a variable that might qualify the selection among young women who are really at a higher risk for HSIL.

\section{Acknowledgments}

We would like to thank the team at Centro de Atenção Integral à Saúde da Mulher, Universidade Estadual de Campinas, São Paulo, Brazil (CAISM-Unicamp/Brazil).

\section{References}

1 Bano F, Kolhe S, Zamblera D, et al. Cervical screening in under 25s: a high-risk young population. Eur J Obstet Gynecol Reprod Biol 2008;139(1):86-89

2 Lowy DR, Schiller JT. Prophylactic human papillomavirus vaccines. J Clin Invest 2006;116(5):1167-1173

3 Schiffman M, Castle PE, Jeronimo J, Rodriguez AC, Wacholder S. Human papillomavirus and cervical cancer. Lancet 2007; 370(9590):890-907

4 Snijders PJ, Steenbergen RD, Heideman DA, Meijer CJ. HPV-mediated cervical carcinogenesis: concepts and clinical implications. J Pathol 2006;208(2):152-164

5 Castanon A, Leung VM, Landy R, Lim AW, Sasieni P. Characteristics and screening history of women diagnosed with cervical cancer aged 20-29 years. Br J Cancer 2013;109(1):35-41

6 Landy R, Birke H, Castanon A, Sasieni P. Benefits and harms of cervical screening from age 20 years compared with screening from age 25 years. Br J Cancer 2014;110(7):1841-1846

7 Popadiuk C, Stankiewicz A, Dickinson J, Pogany L, Miller AB, Onysko J. Invasive cervical cancer incidence and mortality among canadian women aged 15 to 29 and the impact of screening. J Obstet Gynaecol Can 2012;34(12):1167-1176

8 Dickinson J, Tsakonas E, Conner Gorber S, et al; Canadian Task Force on Preventive Health Care. Recommendations on screening for cervical cancer. CMAJ 2013;185(1):35-45

9 Sasieni P, Adams J, Cuzick J. Benefit of cervical screening at different ages: evidence from the UK audit of screening histories. Br J Cancer 2003;89(1):88-93

10 Brasil. Ministério da Saúde. Instituto Nacional de Câncer. [Brazilian cervical cancer screening guidelines]. Rio de Janeiro: INCA; 2016. Portuguese

11 Martínez-Mesa J, Werutsky G, Campani RB, Wehrmeister FC, Barrios $\mathrm{CH}$. Inequalities in Pap smear screening for cervical cancer in Brazil. Prev Med 2013;57(4):366-371

12 Brasil. Ministério da Saúde. DATASUS [Internet]. SISCOLO/SISMAMA. 2014 [citado 2014 Out 01]. Disponível em: http://w3. datasus.gov.br/siscam/index.php

13 Vale DB, Westin MC, Zeferino LC. High-grade squamous intraepithelial lesion in women aged $<30$ years has a prevalence pattern resembling low-grade squamous intraepithelial lesion. Cancer Cytopathol 2013;121(10):576-581

14 Campbell FN, Lara-Torre E. Follow-up compliance of adolescents with cervical dysplasia in an inner-city population. J Pediatr Adolesc Gynecol 2009;22(3):151-155

15 Xavier-Júnior JCC, Vale DB, Vieira LF, Lima MT, Zeferino LC, Dufloth RM. Results of screening for cervical cancer among pregnant and non-pregnant women in Brazil. Int J Gynaecol Obstet 2015;130(1): 36-39

16 Ribeiro AA, Costa MC, Alves RR, et al. HPV infection and cervical neoplasia: associated risk factors. Infect Agent Cancer 2015;10:16

17 Solomon D, Nayar R. The Bethesda System for reporting cervical cytology: definitions, criteria, and explanatory notes. 2nd ed. New York, NY: Springer-Verlag; 2005 
18 National Cancer Institute Workshop. The 1988 Bethesda System for reporting cervical/vaginal cytological diagnoses. JAMA 1989; 262(7):931-934

19 Plummer M, Peto J, Franceschi S; International Collaboration of Epidemiological Studies of Cervical Cancer. Time since first sexual intercourse and the risk of cervical cancer. Int J Cancer 2012; 130(11):2638-2644

20 Louie KS, de Sanjose S, Diaz M, et al; International Agency for Research on Cancer Multicenter Cervical Cancer Study Group. Early age at first sexual intercourse and early pregnancy are risk factors for cervical cancer in developing countries. Br J Cancer 2009;100(7):1191-1197
21 Saslow D, Solomon D, Lawson HW, et al; American Cancer Society; American Society for Colposcopy and Cervical Pathology; American Society for Clinical Pathology. American Cancer Society, American Society for Colposcopy and Cervical Pathology, and American Society for Clinical Pathology screening guidelines for the prevention and early detection of cervical cancer. Am J Clin Pathol 2012;137(4):516-542

22 McCredie MR, Sharples KJ, Paul C, et al. Natural history of cervical neoplasia and risk of invasive cancer in women with cervical intraepithelial neoplasia 3: a retrospective cohort study. Lancet Oncol 2008;9(5):425-434 